\title{
Modeling of development of the internal market of tourist services in Ukraine, based on the principles of cluster management
}

\author{
Mykhailo Sahaidak ${ }^{1, *}$, Valeriia Kostynets $^{2}$ and Iuliia Kostynets $^{3}$ \\ ${ }^{1}$ Kyiv National Economic University named after Vadym Hetman, Department of Economics and Entrepreneurship, Kyiv, Ukraine \\ ${ }^{2}$ Kyiv National University of Technology and Design, Department of Economics and Entrepreneurship, Kyiv, Ukraine \\ ${ }^{3}$ National Academy of Management, Department of Marketing, Economics, Management and Administration, Kyiv, Ukraine
}

\begin{abstract}
The article is devoted to the modeling of the development of the domestic tourist services market in Ukraine on the basis of cluster management. The authors identify trends in the market of tourist services, taking into account behavioral reactions of consumers. The authors determined the main tendency in the Ukrainian market of tourist services, which is the interdependence of the dynamics of consumption of tourist services and material well-being of the middle-income population. The criterial model of development of the tourist region on the basis of cluster management of the internal market of tourist services of Ukraine is developed. The authors noted that, in criterial model the assessment of the level of development of the tourist region is carried out according to several criterias, each of which is estimated using an integrated weighted estimate of a set of indicators, which, using the expert estimation method, allows us to evaluate the factors that form one or another criterion. Critical maps for development of tourist regions of Ukraine are offered: Carpathian region, Polesie region, Central region, Azov-Black Sea region. The principles of development of the internal market of tourist services of Ukraine are determined on the principles of cluster management.
\end{abstract}

\section{Literature review}

Tourism, as one of the most popular phenomena's of the modern period, can be considered a significant socioeconomic and political phenomenon that can affect the economic system and economic development of both individual regions and countries of the world in general. Worldwide experience and practice of ensuring of socioeconomic stability of the developed countries of the world indicates that their geographical location, natural and climatic resources, national traditions and cuisine as well as cultural sights become a common good due to the development of tourism, which, by the efficiency of investments can be equated to a highly profitable industrial business (oil, gas, mining, metallurgical, etc.).

Analyzing the scientific achievements of foreign and domestic scientists, it should be noted that they comprehensively cover the theoretical and practical aspects of the organizational and economic mechanism of the creation and effective functioning of tourism actors.

A. Aleksandrova [1] provides cluster principles of the organization of tourist space in the context of application of the European countries experience. S. Volkov [2] emphasizes the main marketing tools and their use in the tourism business, but does not take into account the characteristics of each separate tourist cluster. S. Ziadin [3] focuses on the segmentation of the market as an instrument for the development of tourist services in one region or another. M. Novelli та B. Schmitz [4] explore clusters solely as innovation in the tourist services market.
O. Pokataieva and G. Kucherova [5] researched innovative approaches to assessing the tourism potential for the formation of clusters in the future. In studies by E. Bordas [6] the development of cooperation between the private and public sectors in the formation of tourist clusters is considered as a new paradigm of development of tourist destinations.

However, the current situation on the markets of tourist services of the countries of the world in the conditions of globalization and glocalization requires constant identification and evaluation of modern socioeconomic aspects of tourism activity, analysis of factors, causes and their consequences, which promote the development of the tourism industry or hinder it. The most significance in this aspect has the development and use of scientific approaches to study the factors of development of the modern market of tourist services, its segmentation, the formation of levers of economic regulation and the improvement of forms and methods of management of tourism activities in the regions, in particular, using a cluster approach in the management of the development of the domestic tourist services market.

\section{Purpose and methods}

The main purpose of research - modeling of development of the internal market of tourist services in Ukraine, based on the principles of cluster management.

\footnotetext{
* Corresponding author: michael p s@ ukr.net
} 
In order to conduct a detailed study, methods of structural-functional analysis, scientific abstractions, as well as graphical and index methods were used.

\section{Analytical data}

In the broadest sense, the market for tourist services is a system of world economic relations, in which the process of reverse transformation of tourist-excursion services into cash and vice versa takes place [1].

Segmentation of the market and the positioning of the tourist product in it are some of the most important components of marketing activity and a powerful tool for increasing the competitiveness of tourism enterprises and the formation of consumer loyalty.

In our opinion, the importance of segmentation increases significantly in the context of a socio-economic or political crisis in the country, since the concentration of efforts of tourism enterprises in the target market segment allows them to increase the competitiveness and efficiency of activities, as well as to save financial resources. Consequently, the selected target segment should be large enough in scope, have growth prospects, provide stronger competitive advantages for the company and be accessible to consumers in terms of prices, sales channels and communications [7].

In turn, determining the target audience of consumers and analyzing their behavior, particularly in the context of reducing purchasing power, is one of the key aspects of adapting of the company's offer to the market environment. In this aspect, it is appropriate to identify several factors that play the most important and decisive role in binding of consumers to the particular tourist enterprise:

1) strong positive emotions, associated with the name of the tourist enterprise in the imagination of consumers;

2) simplification of decision making on the use of other tourist services by reducing the individual risks of the consumer (for example, the non-return of invested funds for the purchase of a tour when it is canceled by the tour operator or the airline; the purchase of a tour in an exotic country, to which, due to number of circumstances, the consumer did not buy tour, because he was not sure about it's quality and safety; prior booking of tours from a proven tour operator, etc.);

3) persuasion of consumers that the offer of tourist products always has a unique value;

4) economic barriers (for example, accumulated by the consumer during cooperation with the tour operator additional bonuses, which can be used for additional free services on the tour);

5) technical barriers (essential changes to the technology of customer service due to termination of cooperation with the tour operator, but the continuation of cooperation with a particular travel agency. That means the impossibility to receive reports on tour offers from the tour operator after the end of use of its services);

6) legal barriers (sanctions for violating the terms of the contract upon termination of cooperation with the tour operator due to it's own fault, or fault of it's counterparties);
7) cognitive barriers (the need for retraining to use technical and electronic devices and programs during the booking of the tour or the independent registration and registration of tickets without the assistance of a tour operator or travel agency manager);

8) spatial barriers (for example, geographical proximity to the office of the tour operator or travel agent; convenience of transfer, location of the hotel and airport, etc.);

9) personal ties (moral obligations in relation to the manager of a tour operator or travel agent) [8].

Consequently, the market of tourist services, as a combination of subject-object relations between producers and consumers of tourist products, are characterized by the following trends:

- the possibility to reduce the number of consecutive days of leave and, at the same time, increasing its frequency, which leads to break-down of the leave into pieces, so one and the same person can carry out several short trips per year (this is especially true for young tourists, who aspire to spend their weekends like this);

- an increase in the "third age" age group of tourists who have time and money for tourist trips, as well as the necessary experience to participate in them;

- the development of special tour operator programs designed for mass tourism, which reduce the cost of tourist trips, which prompts more people to travel;

- the same tourist can visit several countries for one trip, and each new crossing will be considered an international arrival - that means, that in fact, the number of tourists is less than the number of arrivals.

The development of international tourism is characterized by a tendency that the growth rate of tourism revenues is higher than the growth rate of international arrivals. International tourist arrivals 2018 grew $4.9 \%$ in 2017 , and International tourism receipts increased $6.8 \%$ in real terms (adjusted for exchange rate fluctuations and inflation). Total exports from international tourism therefore reach US dollars 1.6 trillion, or US dollars 4 billion a day on average [9].

The process is influenced by the following factors:

- increase in the value of the tourism product (due to the increase in the quality of services, as well as the fact that the tourist product itself is becoming more customized);

- the rising cost of labor in the world, especially in economically developed countries, which account for the majority of the international tourist flow;

- fluctuations in exchange rates. The World Tourism Organization (UNWTO) shows the revenues from international tourism in US dollars and in the euro. Using these currencies as the base currency allows you to make a comparison at the macro level. However, the purchasing power of the dollar and the euro, as well as any other currency, is subject to fluctuations, which affects the dynamics of cost indicators of tourism. Strengthening or weakening of the dollar and the euro relative to the currencies of leading tourist countries can accelerate or, vise-versa, slow down the growth rate of revenues from international tourism;

-inflationary processes, which entail rise of the prices for tourist services. 
It should be noted that if these trends relate to the indicators of the world market of tourist services and take into account the average rates of its development, a detailed study of tourism indicators of specific destinations, countries, subregions and macro regions shows that individual markets of different levels may have their own tendencies, different from the worldwide ones. Thus, in the market of tourist services of Ukraine, the interconnectedness of the dynamics of consumption of tourist services and material well-being of middle-income population is a visible tendency. The current recession in the domestic economy is characterized by a strong fall in real incomes. In recent years, Ukrainians have cut purchases of durable goods and discretionary spending, in particular on expensive travel. For some families, the decline has led to a reduction in the number of trips due to financial constraints, for the others - to reorientation from international tourism to the domestic one.

\section{Results}

Taking into account the above-mentioned tendencies, there is an objective need to develop measures and tools for ensuring the competitiveness of the Ukrainian tourism market as a center for the development of domestic tourism and to take measures to create conditions for conducting such a business, which will increase the efficiency and productivity of domestic tourism and hotel enterprises in the domestic and international markets, as well as to substantially increase the inflow of direct foreign investments into the real sector of the economy.

In our opinion, in modern conditions, the competitiveness of tourist regions of Ukraine on a global scale is directly related to the mechanism of cluster management for the development of the tourism market, in particular, the domestic one (Fig. 1). In the mechanism of cluster management of the development of the domestic tourism market, it is important to identify the means and methods for carrying out targeted state influence, including the influence levers of the local authorities, in order to effectively develop the cluster system of tourist regions of Ukraine (Fig. 1).

The proposed mechanism is the basis for the implementation of cluster policy, as a system of relations between authorities and economic entities to increase the competitiveness of a particular territory on the basis of the formation and development of clusters.

Subjects of cluster policy are legislative and executive bodies of state and / or local authorities, which interact with each other and with business associations, industrial enterprises, educational, scientific and financial institutions, transport and logistics firms, service organizations etc. in the process of its implementation [3].

An interesting experience of effective cluster policy is an example of the development of the Turkish tourism industry. Today, there are 7 efficiently functioning tourist clusters in Turkey: Sultanahmet, Kusadasi, Marmaris, Fethiye, Taksim, Cappodoccia and Antalya.

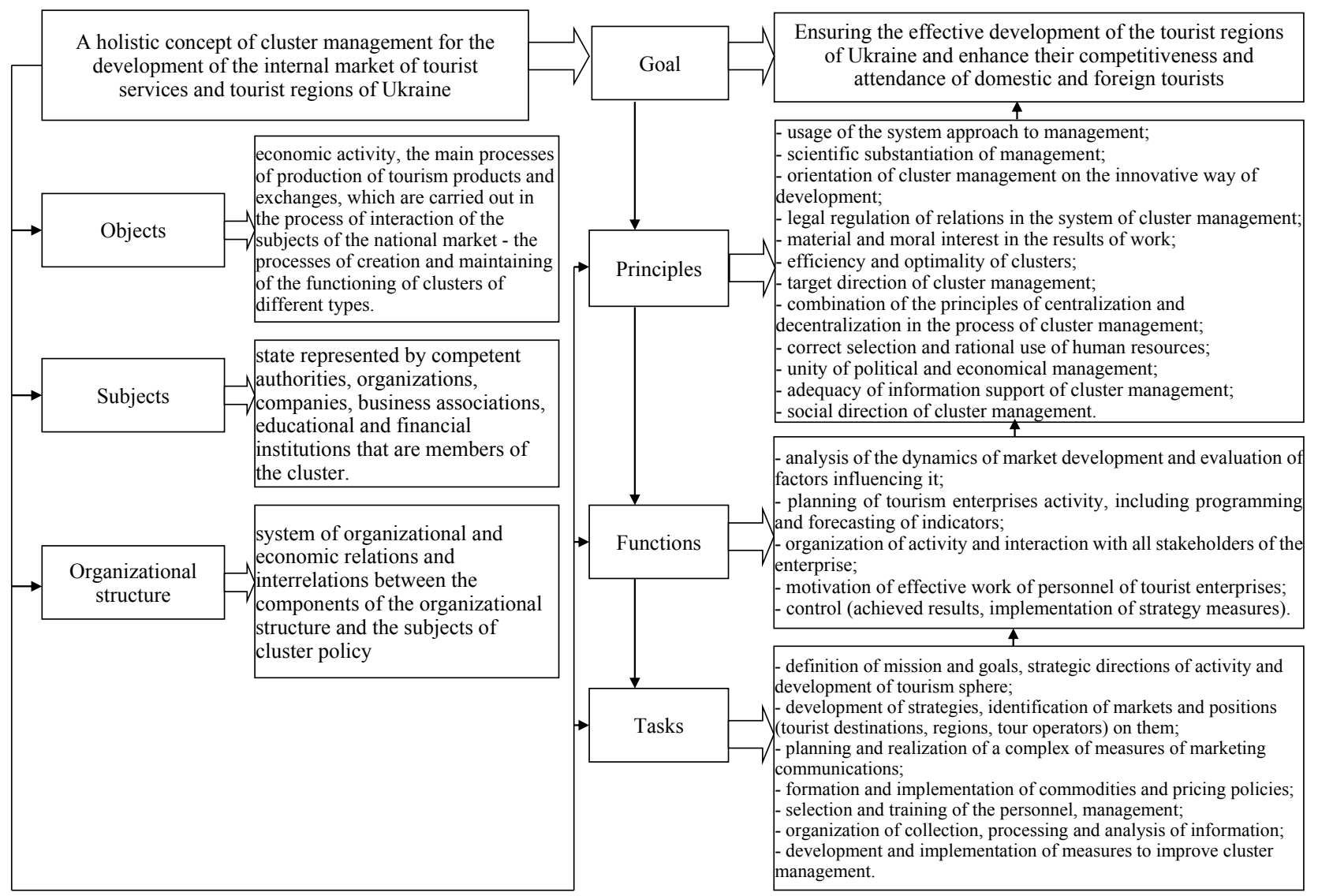

Fig. 1. Structural-logical scheme of the mechanism of cluster management of the development of the internal market of tourist services in Ukraine, compiled by [10]. 
All above-mentioned tourist clusters, except for Sultanahmet and Cappodoccia, are formed on the basis of beach tourism. The most popular and effective is Antalya. It should be noted in particular that beach tourist clusters were formed on the basis of a system of integrated inclination of the "all inclusive" system, which became a marketing component of the national tourism product management strategy [2].

To construct a criterial model of the development of a tourist region based on the principles of cluster management of the internal market of tourist services of Ukraine it is necessary to determine the factors and criterias of clusterization. In order to form effective tourism clusters, it is proposed to take into account the affinity of tourist regions based on the presence of tourist resources, the level of development of tourist infrastructure, etc. In Fig. 2 the criterial model of development of tourist regions of Ukraine is given, which is the basis of calculation of the corresponding integral indices of development of tourist clusters and the internal market of tourist services in general.

In the proposed model, the assessment of the level of development of the tourist region is carried out according to several criterias, each of which is estimated using an integrated weighted estimate of a set of indicators, which, using the expert estimation method, allows us to evaluate the factors that form one or another criterion.

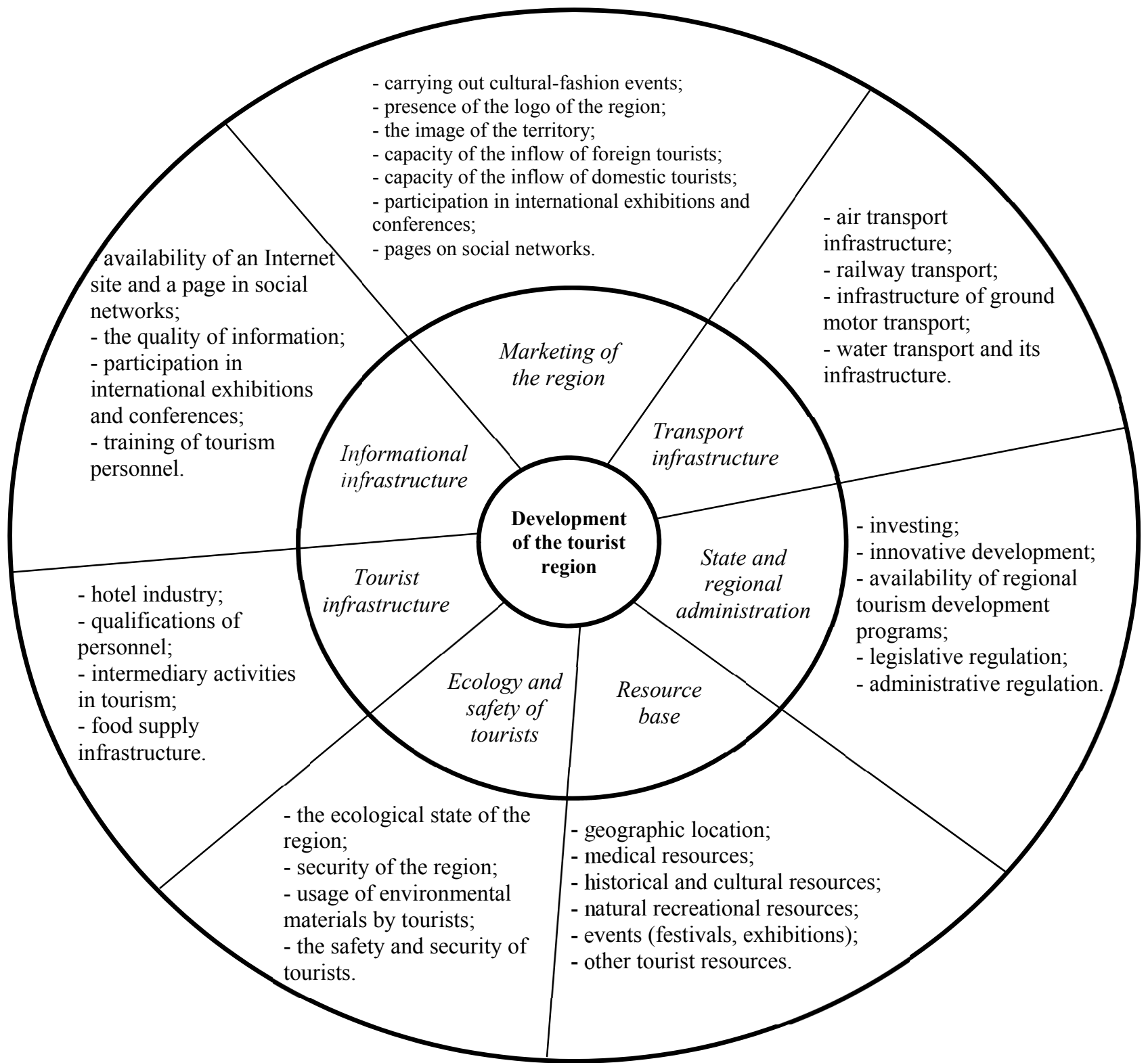

Fig. 2. Criterial model of the development of the tourist region based on the principles of cluster management of the internal market of tourist services of Ukraine. 
The sequence of evaluation is carried out using the index system:

I. The index of development of the tourist region $\left(I_{i}\right)$ :

$$
I_{i}=\sum_{i=1}^{n} \beta_{j} \times G_{j}
$$

where $\beta_{j}$ is the weight of the criterion in the overall assessment of the factors of the region's development;

$G_{j}$ - integral assessment of the criterion.

II. Tourism Cluster Development Index (IRTC):

$$
I R T C=\sum_{i=1}^{n} \alpha_{i} \times I_{i}
$$

where $\alpha_{i}$-weight of the regional development index;

$I_{i}$ - index of the development of tourism in the region.

III. Index of Development of the Internal Market of Tourist Services (IRTM):

$$
I R T M=\sum_{i=1}^{n} \gamma_{i} \times I R T C
$$

where $\gamma_{i}$ - weight of the cluster development index; $I R T C$ - is tourism cluster development index.

\section{Approbation}

Based on the analysis of the selected indicators and the calculation of the relevant criterias of the development of the tourist regions of Ukraine, it is proposed to identify four related regions that can become the basis of the relevant tourist clusters, namely: Carpathian region, Polissya region, Central region, Azov-Black Sea region.

Fig. 3 provides a criterial map of the development of the selected tourist regions, which form tourist clusters in accordance with the level of regional development and available tourist resources. Based on the calculation of the index values of the development criteria, polygons of the development of tourist clusters have been constructed, which also show the strengths and weaknesses of tourist clusters.

Based on the proposed model (Fig. 2), the criterial map of the development of tourist regions of Ukraine on the basis of cluster management of the internal market of tourist services is the basis for the formation of a cognitive model of clusterization of the internal market of tourist services of Ukraine.

As a summary, we should note that measures of the implementation of cluster policy should also be aimed at identifying, forming, supporting and consolidating clusters of small and medium-sized enterprises of tourism business and aimed at satisfying the actual needs of tour operators and travel agents interested in increasing their competitiveness through joint projects within the cluster.

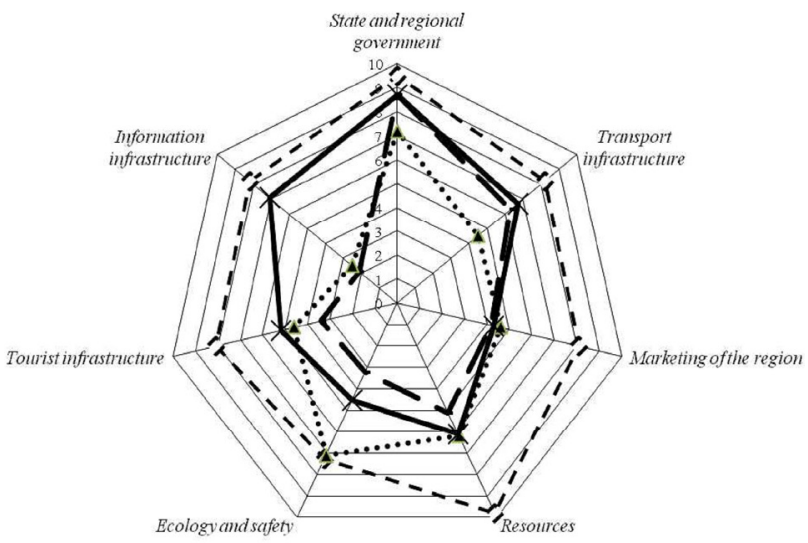

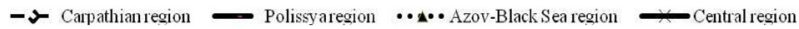

Fig. 3. Criterial map of development of tourist regions of Ukraine as the basis of cluster management of the internal market of tourist services.

In order to implement effective state policy regarding the development of regional tourist clusters and the internal market of tourist services of Ukraine, it is necessary to initially conduct a qualitative research to determine the real number of active associations of tourist enterprises within the cluster. This task should be carried out mainly by local and regional authorities, since they have more differentiated information on the local development of enterprises. At the same time, it is important to provide not only the general control of the activities of tourism enterprises by the authorities for the purpose of paying them taxes and monitoring of the migration processes of the population, but first of all for the development and implementation of an effective mechanism of interaction between government institutions and all stakeholders of tourism enterprises [4]. Equally important is the development of a small and medium-sized business support program in the field of tourism in Ukraine.

In order to enhance the attractiveness of the domestic tourism market as a separate cluster of the world market for tourist services, it is advisable for the state and domestic enterprises of tourism business to interact more closely with foreign tourism companies, in particular by encouraging participation and exchange with foreign clusters, and also using their resources to strengthen their own competitiveness. So, in order to strengthen the uniqueness of the tourist cluster and expand its opportunities not only for survival but also for development in the conditions of global interregional competition, it is necessary to create the basis for open partnership agreements, for example, between foreign companies and institutions of higher education of Ukraine, which train specialists based on educational-professional programs "Tourism and hotelrestaurant business". The use of external resources (engaging foreign partners in the cluster) brings new elements and ideas into the cluster, which allows further 
development of its uniqueness and improves the level of service.

Strategic intercluster exchange should be supported not only by the state, but also by the entities included in the cluster (authorities, organizations, tourism enterprises, business associations, educational institutions, financial institutions etc.).

The obvious advantage of the cluster is its ability to provide inter-industry overflow of labor resources on the principles of self-regulation and self-adaptation to external changes. High adaptability to changes in the marketing environment and the ability to quickly innovate is a decisive advantage of the cluster over other forms of integration.

The subjects of the tourist cluster are usually combined by economic ties and relationships, personal contacts, organizational culture, which includes representations, values, settings, ideals of action, and sometimes a common brand and marketing strategies. These relations are more inclined to institutionalization, which allows to implement long-term projects and deepen mutually beneficial partnerships. In this case, the clustered model of interaction between actors limits the possibility of destructive actions and opportunistic strategies due to competent staffing component and the transparency of the marketing environment, which ultimately promotes mutual adaptation [11].

The need to use the cluster approach for the development of the domestic tourist services market in Ukraine is due, on the one hand, to the unique characteristics of the tourist product, and on the other hand, the benefits arising from the implementation of cluster projects. The advantages of implementing cluster projects in the domestic market of travel services include:

1) the formation of a quality tourist product within the framework of tourist clusters representing the concentration of natural resources and architectural monuments, infrastructure objects, service providers and companies of other related sectors, as well as administrative structures that, when working together, create for tourists a desirable image of visiting one or another destination [6];

2 ) the formation and implementation of targeted and active actions aimed at elimination of potential conflicts and creation of the basis for effective interaction between the subjects of the tourist cluster [12];

3) structuring processes for coordination of the interaction between a large number of participants in the tourist cluster. This allows you to form and offer tourists a specially designed travel package for them, which is complex and unique product. All this updates the need for constant interaction of all subjects of the market of tourist services within the chain of creation of consumer value.

In addition to the above-mentioned undoubted advantages of creation of tourist clusters, their disadvantages should be noted. As stated earlier, the cluster is a form of competitiveness enhancement both within a single country and on international markets. As a result of increased competition with foreign players in the tourist services market, the elasticity of demand for labor in clusters increases, which may lead to stagnant wages or increase of clusters' unemployment rate [13].

As the main problems of developing tourist clusters at the regional level today, the following can be distinguished:

- lack of willingness of senior executives to implement innovations;

- lack of appropriate regional infrastructure and transport accessibility of the regions;

- the need for considerable time to realize the objectives of the tourist cluster.

In Table 1 it is proposed to highlight peculiarities that are inherent to tourist clusters and are substantialized in the theory of organizational development.

Table 1. Characteristics of the principles of development of the internal market of tourist services of Ukraine based on the principles of cluster management.

\begin{tabular}{|c|c|}
\hline Principle & Characteristic \\
\hline Purposefulness & $\begin{array}{l}\text { Focusing on achievement of the objectives of } \\
\text { sustainable development of the territory and the } \\
\text { formation of effective clusters. Cluster policy is } \\
\text { formed only in the case when there are } \\
\text { prerequisites for the creation of similar } \\
\text { structures in the territory. }\end{array}$ \\
\hline $\begin{array}{l}\text { Priority of the } \\
\text { goals of } \\
\text { innovation } \\
\text { development }\end{array}$ & $\begin{array}{l}\text { The content and results of the implementation } \\
\text { of the cluster policy should be innovative, and } \\
\text { proposed measures should support the targeting } \\
\text { of clusters on innovative development }\end{array}$ \\
\hline $\begin{array}{l}\text { Principle of } \\
\text { differentiation } \\
\text { and selectivity } \\
\text { of state support } \\
\text { and regulation } \\
\text { measures } \\
\end{array}$ & $\begin{array}{l}\text { State cluster policy measures are effective only } \\
\text { if they are aimed at direct support of priority } \\
\text { clusters and the creation of favorable conditions } \\
\text { for development of other cluster structures. }\end{array}$ \\
\hline $\begin{array}{l}\text { Complexity of } \\
\text { realization }\end{array}$ & $\begin{array}{l}\text { Cluster policy is designed to unite and } \\
\text { interoperate the interests of various parties } \\
\text { involved in the clusterization process, stimulate } \\
\text { their development, taking into account diverse } \\
\text { interests of the cluster participants, which is } \\
\text { ensured by the integrated development of the } \\
\text { cluster's territorial dislocation. Therefore, the } \\
\text { implementation of partial cluster policy will not } \\
\text { help achieve its target parameters }\end{array}$ \\
\hline Adaptability & $\begin{array}{l}\text { Adaptation of cluster policy to changes in } \\
\text { external and internal conditions of cluster } \\
\text { operation. }\end{array}$ \\
\hline Systemicity & $\begin{array}{l}\text { The concept of systemicity is connected with } \\
\text { the idea of integrity or self-organization: on the } \\
\text { one hand, the cluster is an element of a higher- } \\
\text { level system (the territorial community, region, } \\
\text { country, etc.), and on the other - an independent } \\
\text { system in which various objects and subjects } \\
\text { interact to ensure targeted and coordinated } \\
\text { activities in order to ensure the harmonization } \\
\text { of interests. Accordingly, cluster policy should } \\
\text { focus on the economic and organizational } \\
\text { stimulation of network collaboration and } \\
\text { public-private partnership within the cluster. }\end{array}$ \\
\hline Effectiveness & $\begin{array}{l}\text { The most important effective feature of cluster } \\
\text { policy is the formation of "growth poles", }\end{array}$ \\
\hline
\end{tabular}




\begin{tabular}{|c|l|}
\hline & $\begin{array}{l}\text { which is ensured by obtaining a synergistic } \\
\text { effect from the interaction of business entities in } \\
\text { the process of formation and development of } \\
\text { competitive clusters that are leaders in the } \\
\text { domestic and worldwide markets. }\end{array}$ \\
\hline Expediency & $\begin{array}{l}\text { The need to assess the appropriateness of cluster } \\
\text { policy usage in relation to a particular situation } \\
\text { is due to the presence of the dilemma of "best } \\
\text { practices", since measures for the development } \\
\text { of clusters that have proved effective in one case } \\
\text { may prove to be unfavorable or even } \\
\text { undesirable - in another. }\end{array}$ \\
\hline Hierarchy of & $\begin{array}{l}\text { The cluster strategy should be developed at } \\
\text { different levels of governance: supranational, } \\
\text { national, regional, interregional, sectoral }\end{array}$ \\
\hline
\end{tabular}

The implementation of the above-mentioned approaches and principles for the construction of tourist clusters in Ukraine will increase the effectiveness of their support from the state, substantiate the assessment of opportunities and identify the problems of their functioning, apply the most appropriate methods of management influence. These tools of cluster management will not only save the active role of state institutions, but also other stakeholders who are interested in regulating the rates and quality of economic growth of clusters, as well as contribute to the establishment of centers of competence for economic and innovative development of the country's territories.

\section{Conclusions}

The conducted research allows to confirm, that development of tourist clusters in Ukraine is one of the prerequisites for increase of competitiveness of the domestic market of tourist services, the national economy and intensification of the mechanisms of private-public partnership. The formation of a tourist cluster in modern conditions can be accomplished in the presence of four main components: capital, technology, personnel, recreational resources. Of course, the choice of the territory with the maximum possible location of recreational resources, legal support for the development of tourist clusters and the creation of infrastructure conditions for the activity of small and medium-sized businesses in the field of tourism are of great importance. However, in the face of fierce competition, there is not enough capital to develop tourist enterprises and infrastructural facilities; for the tourism sector, highly skilled and competent workers are required, with knowledge of modern technologies that can teach consumers of tourist services to use innovative software products for the consumption of tourist services (for example, self-check-in on board of the plane, reservation of excursions, purchase of electronic tickets, etc.). Such imbalances of unique resource asymmetries associated with the domination of the human factor over capital, technology and recreational resources will contribute to the formation of sustainable competitive advantages of tourism enterprises of a particular tourist cluster. Hence, intellectual resources (skills, knowledge and abilities, competence and experience of personnel), which are not owned by other enterprises and which cannot be copied even with the correct allocation of costs, will contribute to increase of the competitiveness and further development of the domestic tourist services market in Ukraine.

\section{References}

1. Aleksandrova, A.Yu.: Mezhdunarodnyy turizm (International tourism). Aspekt Press, Moscow (2002)

2. Volkov, S.K.: Zarubezhnyiy i rossiyskiy opyt razvitiya turistskih klasterov (Foreign and Russian experience of tourist cluster development). Scientif. Inform. 16(237), 5-15 (2016)

3. Ziyadin, S.T., Moldazhanov, M.B.: Segmentirovanie rynka kak instrument razvitiya turisticheskih uslug Vostochno-Kazahstanskoy oblasti (Segmentation of the market as a tool for the development of tourism services in the East Kazakhstan region). Bul. of the Alt. St. Agrar. Univ. 11, 127 (2013)

4. Novelli, M., Schmitz, B., Spencer, T.: Networks, clusters and innovation in tourism: A UK experience. Tourism Management. 27(6), 1141-1152 (2006)

5. Pokataieva, O.V., Kucherova, G.Yu.: Innovatsiyni pidhody do otsinky turystychnogo potentsialu Ukrayiny (Innovative approaches to evaluation of tourist potential of Ukraine). East Europe: Econ., Bus. and Manag. 1(06), 154 (2017)

6. Bordas, E.: Improving public-private sectors cooperation in tourism: A new paradigm for destinations. Tourism Review. 56(3/4), 38-41 (2001). doi:10.1108/eb058369

7. Gorelova, T.P., Tultaev, T.A.: Segmentirovanie rynka (Market's segmentation). EAOI, Moscow (2012)

8. Fatkhutdinov, R.A.: Strategicheskiy marketing (Strategic marketing). Piter, Sankt-Petersburg (2000)

9. UNWTO. Tourism Highlights 2018 Edition https://www.slovenia.info/uploads/dokumenti/unwto_t ourism_highlights_2018.pdf(2019). Accessed 28 April 2019

10. Kostynets, Yu.V.: Mehanizm klasternogo upravlinnya rozvytkom natsionalnoy ekonomiky (Mechanism of cluster management for development of the national economy). A.P.E. 12, 83-89 (2017)

11. Aaker, D.A., Moorman C.: Strategic market management. Wiley, New York (2017)

12. Nurgalieva, A.S.: Formirovanie klastera turizma $\mathrm{v}$ Akmolinskoy oblasti (Formation of a tourism cluster in Akmola region). S. Polic. 3, 85 (2010)

13. Friedrichs, Y., Gummesson, E.: Hotel networks and social capital in destination marketing. International Journal of Service Industry Management. 17(1), 58-75 (2006). doi:10.1108/09564230610651589 